doi: 10.18484/2305-0047.2021.6.6719

\author{
Yev.B. RADZISHEVSKA ${ }^{1,2}$, A.S. SAVCHENKO ${ }^{1,4}$, \\ Ya.K. RADZISHEVSKA ${ }^{3}$, O.M. BOIKO ${ }^{3}$, \\ L.A. VYGIVSKA ${ }^{2}$, M. KUKSIN ${ }^{5}$
}

\title{
DEVELOPMENT OF REMOTE SEQUELAE SUCH AS GASTROINTESTINAL TRACT PATHOLOGY IN PATIENTS SPECIALLY TREATED FOR DIFFERENTIATED THYROID CANCER
}

\author{
S.P. Grigoriev Institute of Medical Radiology and Oncology \\ of the National Academy of Medical Sciences of Ukraine ${ }^{1}$, \\ Kharkiv National Medical University ${ }^{2}$, \\ Kharkiv City Clinical Hospital No27 ${ }^{3}$, \\ Kharkiv State University named after V.N.Karazin ${ }^{4}$, Kharkiv, \\ Ukraine \\ École Normale Supérieure 5, Lyon, France
}

Цель. Оценить возможные отдаленные эффекты лечения дифференцированного рака щитовидной железы (ДРЩЖ) в виде патологий желудочно-кишечного тракта (ЖКТ) на основании катамнестических данных историй болезни пациентов с ДРЩЖ.

Материалы и методы. Изучались вопросы развития отдаленных последствий в виде патологий ЖКТ на катамнестических данных 157 пациентов с ДРЩЖ, которые проходили лечение по стандартной схеме, включающей радикальное хирургическое лечение, радиойодтерапию и гормонотерапию. База данных для проведения исследования содержала в максимально доступном объеме оцифрованные данные бумажных историй болезни с периодом наблюдения более 1 года после лечения. Количество логических записей об отдаленных последствиях составляло 463 единицы - одна запись на одно последствие каждого из 157 пациентов. Исследование проводилось по двум направлениям: сравнение частот встречаемости патологий ЖКТ до начала лечения и на отдаленных сроках после проведенного специального лечения и выявления факторов статистически значимого влияния на появление патологий ЖКТ среди характеристик лечения.

Результаты. Выявлено, что общее количество патологий ЖКТ увеличилось в 1,6 раза при статистически значимых изменениях в частоте встречаемости со стороны желчного пузыря, печени и поджелудочной железы. Показано, что у пациентов с патологией желчного пузыря по сравнению с пациентами без патологии была ниже продолжительность супрессивной гормонотерапии (4 месяца против 13 месяцев) и были ниже дозы L-тироксина на фоне некомпенсированного гипотериоза (2,3 мкг/кг против 3,5 мкг/ кг). Выявлена статистически значимая связь между суммарной длительностью лактации при нарушениях метаболического здоровья у женщин и развившейся в будущем патологией печени (преимущественно неалкогольного стеатогепатита).

Заключение. Обоснованным элементом пожизненного постлечебного мониторинга пациентов, проходивших специальное лечение ДРЩЖ, должно быть обязательное всестороннее исследование состояния органов ЖКТ.

Ключевые слова: дифференцированный рак щитовидной железы, отдаленные последствия, патологии желудочно-кишечного тракта, гипотериоз, дозы L-тироксина, метаболическое здоровье у женщин, длительность лактации

Objective. Evaluate the potential long-term effects of differentiated thyroid cancer (DTC) treatment, on the gastro-intestinal tract (GIT) based on a retrospective study of DTC patients.

Methods. Occurrence of long-term GIT pathologies was retrospectively studied in 157 DTC patients. All patients were treated according to the standard of care, which includes radical surgery, radiation therapy and hormone therapy. The database contained digitalised medical histories of patients followed for at least 1 year after treatment. A total of 463 entries were available, representing one entry per noted consequence for each of the 157 patients. The study focused on two aspects. The frequencies of complications before and after treatment were compared, and factors impacting DTC pathology in a statistically significant manner were isolated.

Results: The total onset frequency of gallbladder, liver and pancreas disorders was increased by a factor of 1.6 in a statistically significant manner in DTC patients. Patients initially presenting gallbladder disorders received shorter cures of hormone therapy (4 versus 13 months), and lower levels of L-thyroxine in a context of uncompensated 
hypothyroidism (2.3 versus $3.5 \mathrm{mg} / \mathrm{kg}$ ). A statistically significant relation was established between the total duration of breastfeeding in women presenting metabolic health disorders, and onset of liver pathology (essentially nonalcoholic steatohepatitis).

Conclusion. Life-long GIT pathology monitoring should be standard of care for patients after special DTC treatment.

Keywords: Differentiated thyroid cancer, long-term effects, gastro-intestinal tract disorders, hypothyroidism, L-thyroxine dose, metabolic health in women, breastfeeding duration

Novosti Khirurgii. 2021 Nov-Dec; Vol 29 (6): 719-727

Development of Remote Sequelae such as Gastrointestinal Tract Pathology

in Patients Specially Treated for Differentiated Thyroid Cancer

Yev.B. Radzishevska, A.S. Savchenko, Ya.K. Radzishevska, O.M. Boiko, L.A. Vygivska, M. Kuksin

The articles published under CC BY NC-ND license

\section{Научная новизна статьи}

Впервые проведен анализ отдаленных эффектов лечения дифференцированного рака щитовидной железы в виде патологий желудочно-кишечного тракта. Установлено, что количество патологий увеличилось в 1,6 раза в основном со стороны желчного пузыря, печени и поджелудочной железы. Установлено, что патология желчного пузыря типична для пациентов с коротким этапом супрессивной гормонотерапии и низкой дозой L-тироксина на фоне некомпенсированного гипотериоза. Выявлена связь между суммарной длительностью лактации при нарушениях метаболического здоровья у женщин и развившейся в будущем патологией печени.

\section{What this paper adds}

The long-term effects of treatment of differentiated thyroid cancer on the gastro-intestinal tract have never been described to date. Here, a 1.6-fold increase in disorders implicating mainly the gallbladder, liver and pancreas is noted. Gallbladder disorders are shown to be frequent in patients undergoing short courses of thyroid hormone suppression therapy with low levels of L-thyroxine and presenting uncompensated hypothyroidism. In women presenting metabolic disorders, a relation has been established between the total duration of breastfeeding and the later development of liver pathologies.

\section{Introduction}

Today, differentiated thyroid cancer (DTC) is the most common tumor of the endocrine system and accounts for $1.0-2.2 \%$ of all malignant neoplasms [1]. Over the past two decades, this cancer has been recognized as an independent statistical unit in oncology statistics.

The number of newly diagnosed cases has been growing over the past three decades on all continents except Africa, which may be due to an insufficient degree of detection of this pathology. According to the latest data, DTC is the fifth most common cancer among women (in Italy, the second most common cancer in women under the age of 45) [1]. Only in a few countries (Norway, Sweden) the incidence of DTC is gradually decreasing and is about 3.0 cases per 100 thousand inhabitants [1].

The issues of life quality at the remote stages of anticancer treatment do not lose their relevance [2, $3]$. The special treatment program for thyroid cancer involves the sequential use of surgical treatment, radionuclide therapy (RNT), and hormone therapy. In this case, each link of the treatment process, theoretically, can become a factor initiating the emergence of undesirable consequences of treatment in the future, in particular, somatic [4].

The authors' clinical experience as well as the results of previous studies and analysis of literature sources indicate that RNT and suppressive hormone therapy in patients with thyroid cancer leads to longterm consequences from the cardiovascular system
$[5,6,7,8]$, the female genital area $[9,10]$, the musculoskeletal system [11, 12, 13], the endocrine system [14], the organs of vision [15, 16].

Against the background of a fairly active discussion of the complications described above, there are practically no works devoted to the state of the gastrointestinal tract (GIT) in DTC patients in the long term period after treatment, although the results of the author's own observations indicate rather a high incidence of the digestive system pathology. The proposed work is devoted to this problem, which is a fragment of research work (State institution "Institute of Medical Radiology and Oncology named after S.P. Grigoriev of the National Academy of Medical Sciences of Ukraine" (State Institution "IMRO NAMS of Ukraine")) "To evaluate the risks of remote oncologic and somatic neurological consequences of thyroid cancer treatment for substantiating the clinical and methodological support of special therapy" (hereinafter - Research).

A possible way of obtaining new knowledge in the medical field is the approaches of the Data Mining technology used in relation to the digitized arrays of case histories. Data Mining, in the most general sense, is a technology for detecting information in databases. The most general definition of Data Mining can be formulated as follows: it is a technology for detecting "raw" previously unknown non-trivial data, available and practically useful, necessary for making decisions in various spheres of human activity. 
The State Institution "IMRO NAMS of Ukraine" is one of the leading institutions in Ukraine for the treatment of thyroid pathology and it has an extensive archive of paper case histories, which have been indexed in the service database since 1992 .

To carry out a full-volume research, the analytical database "Programs for the cancer patients treatment " was filled with information. This software is the development of the Institute (certificate of copyright registration for the software product No. 65009 dated 04.21.2016) and allows keeping in a formalized form all the elements of paper patient records, including the results of posttreatment screenings.

Objective. To evaluate the potential long-term effects of differentiated thyroid cancer (DTC) treatment on the gastro-intestinal tract (GIT) based on a retrospective study of DTC patients.

\section{Methods}

The follow-up data are studied of 157 individuals have been under the combined treatment for thyroid cancer in the clinic of the Institute since 1993. The criterion for enrolling into the electronic database was:

- availability of all stages of special treatment;

- regular screening examinations after finishing special treatment;

- development of any complication after 1 year from the moment of the thyroid ablation achievement as a criterion for the completion of radioiodine therapy, or the absence of any undesirable long-term consequences after 5 or more years.

The analytical database compiled for the Research contained the following characteristics of patients: gender, age of the patient at the time of diagnosis and at the time of occurrence of the separated consequences, stage of the underlying disease, histological structure of the tumor, concomitant diseases, bad habits, heredity, gynecological history data, detailed characteristics of RIT, characteristics of hormone therapy at all stages after RIT until the last moment of observation (suppressive (SHT), replacement (RHT)), the degree of compensation for postoperative hypothyroidism (compensated, uncompensated $(\mathrm{NH})$ ). The degree of compensation was assessed on the basis of the dynamics of TSH indices and the dose of thyroxine taken.

The diagnoses were established in accordance with the International Classification of Diseases $\mathrm{X}$ revision and on the basis of existing regulatory documents.

According to the stages of the underlying disease, the patients were distributed as follows:

T1bN0M0 $62(39,5 \%)$ patients

T2N0M0 $57(36,3 \%)$ patients
T1-3N0-1aM0 24 (15,3\%) patients

T1-4 N0-1a,bM0- 14 (9\%) patients.

According to the histological structure, 126 (80.3\%) patient had papillary cancer and 25 people $(16 \%)$ had follicular cancer. Papillary-follicular cancer was diagnosed in 6 patients (3.7\%). Invasion of the thyroid capsule was observed in 38 patients (24.2\%).

The age of the patients ranged from 13 to 76 years with a median of 48 years and an interquartile range (IR) of $40-56$ years.

Among the patients there were 27 men (17.2\%) and 130 women $(82.8 \%)$.

In 12 patients (7.4\%), no long-term effects of treatment were recorded.

The median of the total activity of 131I was $4440 \mathrm{MBq}, \mathrm{IR}=3050-7400 \mathrm{MBq}$.

The number of logical records about longterm consequences in the formed database was 463 units - one record for one consequence of each of 157 patients. The unique code of each record contained information about the body system and a specific nosology. Thus, the analyzed database was a complete array of long-term outcomes of special treatment for thyroid cancer, taking into account oncologic and somatic consequences.

\section{Statistics}

To advance hypotheses, the WizWhy software of the DataMining category was used in the work. Hypothesis testing was carried out by methods of nonparametric statistics using the general-purpose software package STATISTICA (LicenseNumber: 139-956-866).

To assess the statistical significance of the differences in the frequency of occurrence of the trait, a nonparametric Pearson's Chi-squared test was used; to identify differences between the indices of the interval scale of unrelated groups, the nonparametric Mann-Whitney test was used, for related groups - the Wilcoxon test. As descriptive statistics, we used the median as an indicator of the central tendency and the interquartile range as an indicator of the spread, the minimum and maximum sample values.

\section{Results}

The study of the possible effect of the treatment on the occurrence of gastrointestinal tract pathologies was carried out in two main directions:

- comparison of the frequency of gastrointestinal tract pathologies at the beginning of treatment and in the long term after the treatment;

- determining differences between the characteristics of patients who had and had no complications from the gastrointestinal tract after 
one or more years after treatment.

Pathologies of the gallbladder, liver pathology, stomach pathology, intestinal pathology, and pancreatic pathology were investigated as possible side effects of special treatment on the part of the digestive system.

At the time of special treatment start, the aggravation of the condition of patients with gastrointestinal tract pathology was characterized by the following figures (according to a database of 463 entries): gallbladder pathology - 90 cases, liver pathology - 26 cases, stomach pathology - 36 cases, intestinal pathology - 19 cases, pancreatic pathology glands - 14 cases. The total number of gastrointestinal tract pathologies was $40.0 \%$.

After special treatment, the total number of gastrointestinal tract pathologies reached the level of $65.4 \%$, that is, increased by 1.6 fold. In particular, the total number of gallbladder diseases increased by 46 cases and reached the level of $29.4 \%$ versus $19.4 \%$ at the beginning of treatment $(p=0.02)$; the number of stomach diseases increased by 16 cases and reached the level of $11.23 \%$ versus $7.8 \%$ at the beginning of treatment $(\mathrm{p}=0.08)$; the number of liver diseases increased by 36 cases and amounted to $13.4 \%$ versus $5.6 \%$ at the beginning of treatment (p $<0.01)$; the number of pancreatic diseases increased by 16 cases and reached the level of $6.5 \%$ versus $3.0 \%$ at the beginning of treatment $(p=0.01)$; the number of bowel diseases increased by 4 cases $(5 \%$ versus $4.1 \%$ at the beginning of treatment ( fig. 1).

The time median for the onset of gastrointestinal consequences was 3.6 years, $\mathrm{IR}=1.5-6.8$ years.

Thus, the largest number of new cases of diseases of the digestive system was observed from the side of the gallbladder, the next most common were liver pathologies, diseases of the stomach and pancreas. The colon and duodenum were the least affected. The differences in frequencies before and after treatment from the side of the gallbladder, liver and pancreas were statistically significant.

The influence of the age factor on the increase in the morbidity level of the digestive system in the long term after special treatment was not revealed; the median value of the age of patients at the beginning of treatment was 49 years, after treatment - 51 years $(p>0.05)$.

Further studies aimed at finding possible risk factors for the development of gastrointestinal pathologies were carried out using the DataMining technology and made it possible to identify a number of statistically significant dependencies.

In particular, statistically significant relationships were found between the appearance of gallbladder pathologies, the duration of suppressive therapy ( $p$ $<0.01$ ), and the dose of L-thyroxine in NH (Fig. 2, 3).

Patients with the gallbladder pathology had a shorter duration of SHT (4 months versus 13 months) and a lower dose of L-thyroxine against the background of $\mathrm{NH}(2.3 \mathrm{~g} / \mathrm{kg}$ versus $3.5 \mathrm{~g} / \mathrm{kg})$.

The statistically significant relationship $(p=0.047)$ found between the total duration of lactation in women and the developed liver pathology in the long term after special treatment (Fig. 4) is quite nontrivial.

As one can see in the above graph, in women with thyroid cancer who did not have liver complications, the median total lactation period was 3 months, and in women with pathology 9 months with a maximum value of 15 months.

Out of 130 women with DTC, whose medical history was considered in the study, as a concomitant disease at the time of the start of special treatment, liver pathology was recorded in 24 patients (18.5\%). After the treatment, 23 cases (21.7\%) of liver disease were detected for the first time, in the overwhelming majority - non-alcoholic steatohepatitis (18 cases).

In terms of age characteristics, no differences were found between women with post-treatment

Fig. 1. The number of gastrointestinal tract pathologies before and after treatment

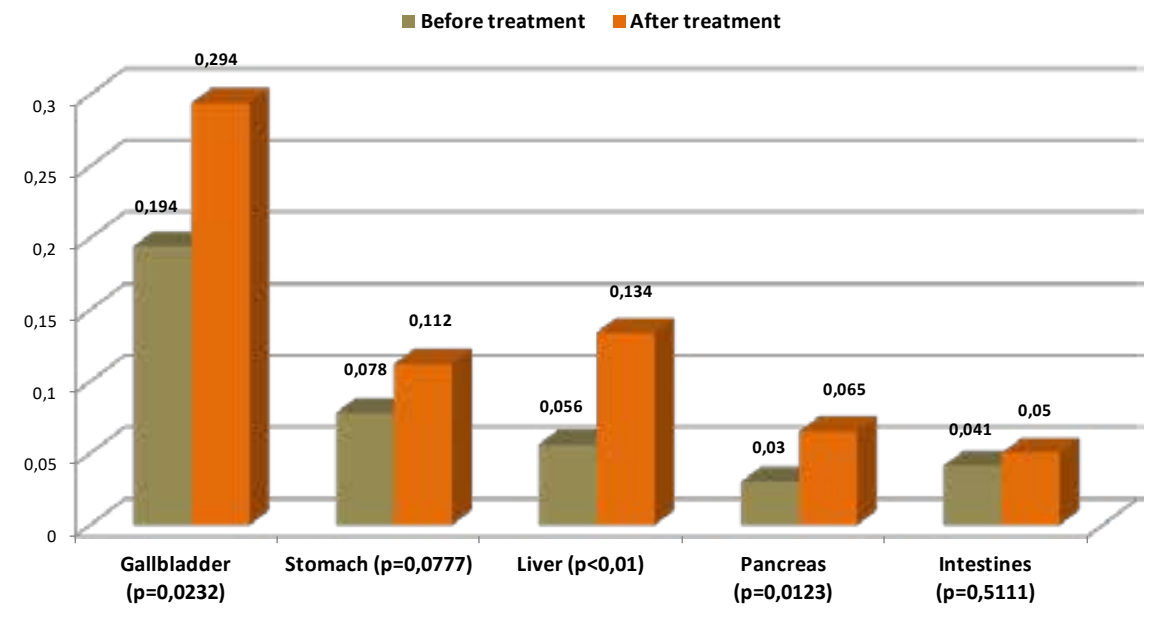




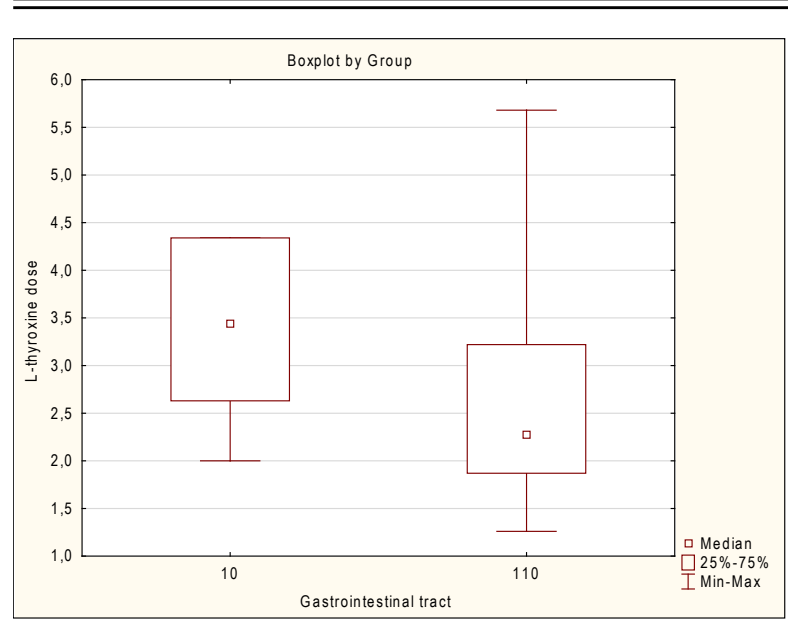

Fig. 2. Dose of hormones per $1 \mathrm{~kg}$ of body weight in patients with NH during hormone therapy. 10 - group of patients without gastrointestinal tract pathologies; 110 - a group of patients with gallbladder pathology.

liver pathology and women who did not develop pathology (median 45 years and 47 years, respectively).

Differences in body mass indices were statistically significant $(\mathrm{p}=0.029)$ : median $29 \mathrm{~kg}$ / $\mathrm{m} 2, \mathrm{IC}=24$ ч 32 in women without pathology; median $32 \mathrm{~kg} / \mathrm{m} 2, \mathrm{IR}=28$ ч 37 in women with pathology.

It is noteworthy that at the time of the start of special treatment, no differences in the total duration of lactation between women with liver pathology and without it were found.

\section{Discussions}

The state of the digestive system in patients undergoing DTC treatment is presented in the

Fig. 4. Duration of lactation in patients with the liver complications and without gastrointestinal tract pathologies. 10 - the group of patients without gastrointestinal tract pathologies; 110 - the group of patients with gallbladder pathology.

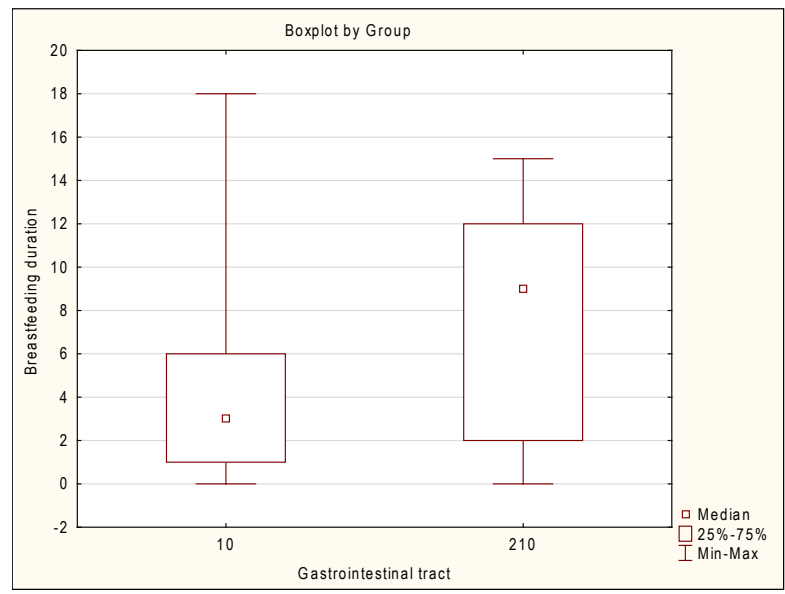

10 - group of patients without gastrointestinal tract pathologies; 210 - group of patients with the liver pathology

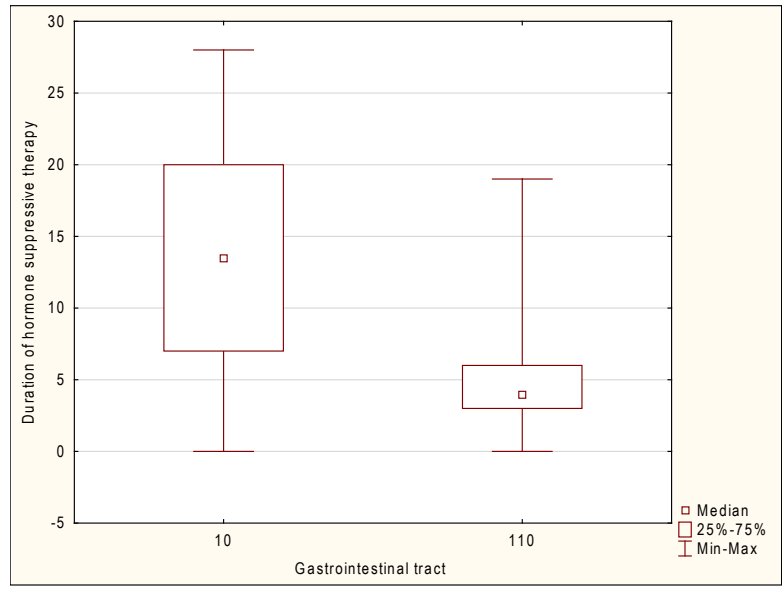

Fig. 3. Duration of SHT in patients with complications from the gallbladder and in patients without gastrointestinal tract pathologies. 10 - the group of patients without gastrointestinal tract pathologies; 110 - the group of patients with gallbladder pathology.

literature by a limited number of publications. At the same time, a comprehensive analysis of the long-term and long-term somatic consequences of special treatment, carried out by the authors in the research, allows us to draw conclusions about the fairly widespread prevalence of complications in this category.

Target organs, pathological changes of which are statistically significant, are the gallbladder, liver and pancreas. At the same time, the organs of secretion, the liver and pancreas - were the most vulnerable: here the number of newly emerging pathologies was 2 or more times higher than their initial frequency of occurrence. Noteworthy is the common embryogenesis of both organs (their development in the 3rd week from the endoderm of the midgut), as well as the biosynthetic function characteristic of both.

Relation to the pancreas, no specific provocative factors of treatment were identified and, apparently, the identified deviations are cumulative in nature, due to all components of treatment.

The pathology of the gallbladder was typical for patients who during hormonal therapy were in a state of NH for a longer time against the background of low doses of L-thyroxine, and less in a state of suppression. From our point of view, this is due to the fact that a low dose of the hormone provoked a slowdown in all biological processes in the body, in particular, a decrease in motor-evacuation function, which led to stagnation of bile and damage to the gallbladder.

Thus, episodes of insufficient compensation during hormone therapy with low doses of L-thyroxine with a short suppressive period (from 3 months to 6 months) are a risk factor for the occurrence of gallbladder pathology in the future. 
Rather an unexpected result of the study was a logical rule revealed using the DataMining technology, linking the appearance of liver pathology with the duration of lactation in women with DTC in the long term after treatment.

Among the sources of evidence-based medicine available for study, the state of the liver from the point of view of somatic consequences was considered in work [13]. However, this publication is devoted to the study of the biochemical state of the liver, not in the long term, but during the period of RIT. At the same time, the authors draw attention to more pronounced changes in liver function in the female subgroup compared to the male.

The metabolic relationship between the liver and the mammary gland during lactation is fairly well understood. Glucose synthesized by the liver enters the bloodstream and is absorbed by the mammary glands, where the main metabolic products are synthesized: milk sugar (lactose) and triglycerides, the base of milk fat [14]. At the same time, the question of the effect of breastfeeding on the mother's metabolism in the long term remains controversial. Some authors believe that longer lactation is associated with a decrease in the prevalence of nonalcoholic fatty liver disease in women [15].

Another part of the researchers does not support the idea of the relationship between the duration of lactation and the metabolic health (MH) of a woman and they believe that women with more favorable $\mathrm{MH}$ parameters at the time of breastfeeding start are characterized by a longer period of breastfeeding and come out with better MH characteristics compared to women who initially had worse MP [16].

At the same time, there are no data that directly relate to the results of treatment of women with DTC and in which we are talking about the association: a long period of breastfeeding the risk of developing steatohepatitis in the future. However,

Fig.5 Body scintigraphy data on «residual» activities on the 3rd and $7^{\text {th }}$ days after RIT.

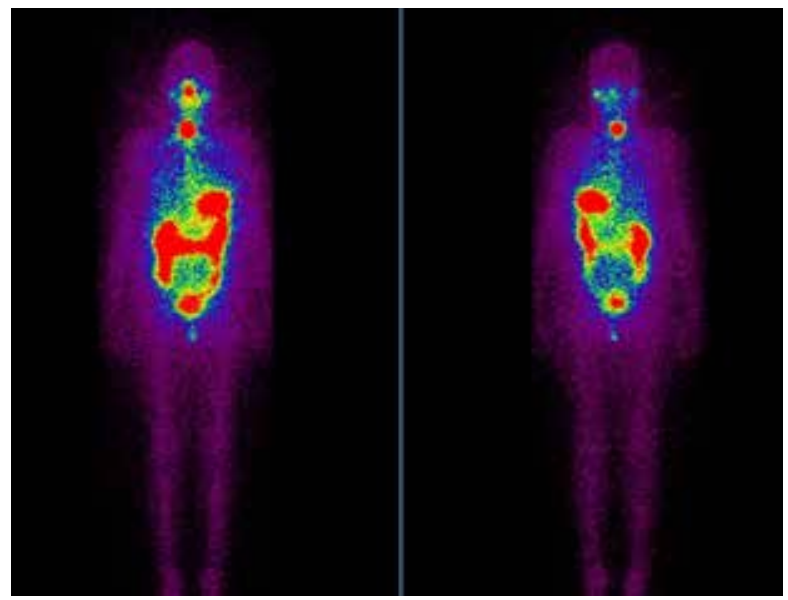

personal observations and clinical experience of the authors indicate rather characteristic phenotype of women who develop steatohepatitis in the long term after special treatment. As a rule, these are women who are overweight, with a fairly long lactation period, episodes of $\mathrm{NH}$ in the presence of hormone therapy. Thus, it cannot be ruled out that in patients with unfavorable $\mathrm{MH}$ parameters and a long lactation period, complications of the combined treatment of thyroid cancer from the liver (steatohepatitis) are quite typical.

In addition, it should be noted that hormones (especially thyroxine and steroid hormones estrogens, cortisol and aldosterone) undergo chemical transformations in the liver, which makes it possible to consider the revealed logical rule to have the right to exist and to recommend targeted screening of the MH state and liver state after recovery for this category of patients.

The pathologies of the gastrointestinal tract identified by us in patients undergoing special treatment for DTC are quite expected. Figure 5 below shows the physiological accumulation of ${ }^{131}$ I on days 3-7 after RIT. The half-life of ${ }^{131} \mathrm{I}$ is 9.5 days, however, taking into consideration the typical for this category of patients violations of the motor-evacuation function of the gastrointestinal tract against the background of uncompensated postoperative hypothyroidism, all parts of the gastrointestinal tract are exposed to incorporeal irradiation, the severity of which depends primarily on the total radiation dose.

From all of the above, one should conclude that a justified element of lifelong post-treatment monitoring of patients undergoing special treatment for DTC must be a mandatory comprehensive study of the state of the gastrointestinal tract.

\section{Conclusion}

The state of the gastrointestinal tract in patients with long-term DTC after special treatment is rarely discussed in the modern literature. However, this study indicates a statistically significant increase in pathological changes in the gallbladder, liver, and pancreas, caused both by the consequences of incorporated irradiation during RIT and by episodes of decompensated hypothyroidism. In addition, it was shown that the risk group in relation to the development of steatohepatitis are females with unfavorable parameters of metabolic health and a long lactation period in history. Thus, taking into account the current priorities of the healthcare system aimed at improving the quality of life of cured cancer patients, control over the gastrointestinal tract state should be an obligatory element of post-treatment monitoring. 
Funding

The research was carried out in accordance with the research plan of the Institute of Medical Radiology and Oncology named after V.I. S.P. Grigoriev, National Academy of Medical Sciences of Ukraine. The authors did not receive financial support from the drug manufacturers.

\section{Conflict of interests}

There is no any conflict of interests.

\section{Acknowledgments}

The authors express their deep gratitude to the highly professional bibliographer T.V. Galchenko for the invaluable assistance provided in conducting information retrieval.

\section{ЛИТЕРАТУРА}

1. Pellegriti G, Frasca F, Regalbuto C, Squatrito $\mathrm{S}$, Vigneri R. Worldwide increasing incidence of thyroid cancer: update on epidemiology and risk factors. $J$ CancerEpidemiol. 2013;2013:965212. doi: $10.1155 / 2013 / 965212$

2. Древаль АВ, Нечаева ОА, Гарбузов ПИ, Мамедова ТР, Чих ИД, Крылов ВВ. Показатели качества жизни, психоэмоциональный статус больных диффузным токсическим зобом в отдаленные сроки после радиойодтерапии. Проблемы Эндокринологии. 2013;(3):13-18. https://doi.org/10.14341/prob1201359313-18

3. Yoo SH, Choi-Kwon S. Changes in quality of life and related factors in thyroid cancer patients with radioactive iodine remnant ablation. $J$ Korean Acad Nurs. 2013 Dec;43(6):801-11. doi: 10.4040/ jkan.2013.43.6.801

4. Parker WA, Edafe O, Balasubramanian SP. Longterm treatment-related morbidity in differentiated thyroid cancer: a systematic review of the literature. Pragmat Obs Res. 2017 May 16;8:57-67. doi: 10.2147/ POR.S130510. eCollection 2017.

5. Klein Hesselink EN, Klein Hesselink MS, deBock GH, Gansevoort RT, Bakker SJ, Vredeveld EJ, vander Horst-Schrivers AN, vander Horst IC, Kamphuisen PW, Plukker JT, Links TP, Lefrandt JD. Long-term cardiovascula rmortality in patients with differentiated thyroid carcinoma: anobservational study. J ClinOncol. 2013 Nov 10;31(32):4046-53. doi: 10.1200/JCO.2013.49.1043

6. Abdulrahman RM, Delgado $\mathrm{V}$, Hoftijzer $\mathrm{HC}, \mathrm{Ng}$ AC, Ewe SH, Marsan NA, Holman ER, Hovens GC, Corssmit EP, Romijn JA, Bax JJ, Smit JW. Both exogenous subclinical hyperthyroidism and short-term overt hypothyroidism affect myocardial strain in patients with differentiated thyroid carcinoma. Thyroid. 2011 May;21(5):471-76. doi: 10.1089/thy.2010.0319

7. Sawka AM, Lakra DC, Lea J, Alshehri B, Tsang RW, Brierley JD, Straus S, Thabane L, Gafni A, Ezzat S, George SR, Goldstein DP. A systematic review examining the effects of therapeutic radioactive iodine on ovarian function and future pregnancy in female thyroid cancer survivors. Clin Endocrinol
(Oxf). 2008 Sep;69(3):479-90. doi: 10.1111/j.13652265.2008.03222.x

8. Metso S, Jaatinen P, Huhtala H, Luukkaala

T, Oksala H, Salmi J. Long-term follow-up study of radioiodine treatment of hyperthyroidism. Clin Endocrinol (Oxf). 2004 Nov;61(5):641-48. doi: 10.1111/j.1365-2265.2004.02152.x

9. Zhang P, Xi H, Yan R. Effects of thyrotropin suppression on lumbar bone mineral density in postmenopausal women with differentiated thyroid carcinoma. Onco Targets Ther. 2018 Oct 9;11:6687-92. doi: 10.2147/OTT.S171282. eCollection 2018.

10. Blackburn BE, Ganz PA, Rowe K, Snyder J, Wan Y, Deshmukh V, Newman M, Fraser A, Smith K, Herget K, Kim J, Kirchhoff AC, Porucznik C, Hanson H, Abraham D, Monroe M, Hashibe M. Reproductive and gynecological complication risks among thyroid cancer survivors. J Cancer Surviv. 2018 Oct;12(5):70211. doi: $10.1007 / \mathrm{s} 11764-018-0707-7$

11. Samadi R, Ghanbari M, Shafiei B, Gheibi S, Azizi F, Ghasemi A. High dose of radioactive iodine per se has no effect on glucose metabolism in thyroidectomized rats. Endocrine. 2017 May;56(2):399-407. doi: 10.1007/ s12020-017-1274-9

12. Lin SY, Hsu WH, Lin CL, Lin CC, Lin JM, Chang YL, Hsu CY, Kao CH. Evidence for an Association between Macular Degeneration and Thyroid Cancer in the Aged Population. Int J Environ Res Public Health. 2018 May 3;15(5):902. doi: 10.3390/ijerph15050902

13. Wang S, Liang $C$, Zhao L, Meng Z, Zhang C, Jia Q, Tan J, Yang H, Liu X, Wang X. Influence of radioactive iodine therapy on liver function in patients with differentiated thyroid cancer. $\mathrm{Nucl} \mathrm{Med}$ Commun. 2018 Dec;39(12):1113-20. doi: 10.1097/ MNM.0000000000000919

14. Rawson P, Stockum C, Peng L, Manivannan B, Lehnert K, Ward HE, Berry SD, Davis SR, Snell RG, McLauchlan D, Jordan TW. Metabolic proteomics of the liver and mammary gland during lactation. $J$ Proteomics. 2012 Jul 19;75(14):4429-35. doi: 10.1016/j. jprot.2012.04.019

15. Ajmera VH, Terrault NA, VanWagner LB, Sarkar M, Lewis CE, Carr JJ, Gunderson EP. Longer lactation duration is associated with decreased prevalence of nonalcoholic fatty liver disease in women. J Hepatol. 2019 Jan;70(1):126-32. doi: 10.1016/j.jhep.2018.09.013

16. Velle-Forbord V, Skrestad RB, Salvesen Ø, Kramer MS, Morken NH, Vanky E. Breastfeeding and long-term maternal metabolic health in the HUNT Study: a longitudinal population-based cohort study. BJOG. 2019 Mar;126(4):526-34. doi: 10.1111/14710528.15538

\section{REFERENCE}

1. Pellegriti G, Frasca F, Regalbuto C, Squatrito $\mathrm{S}$, Vigneri $\mathrm{R}$. Worldwide increasing incidence of thyroid cancer: update on epidemiology and risk factors. $J$ CancerEpidemiol. 2013;2013:965212. doi: $10.1155 / 2013 / 965212$

2. Dreval' AV, Nechaeva OA, Garbuzov PI, Mamedova TR, Chikh ID, Krylov VV. Quality of life indices and psychoemotional status of the patients presenting with diffuse toxic goiter during the longterm follow-up after iodine radiotherapy. Problems of Endocrinology. 2013;59(3):13-18. https://doi. org/10.14341/probl201359313-18c (In Russ.)

3. Yoo SH, Choi-Kwon S. Changes in quality of 
life and related factors in thyroid cancer patients with radioactive iodine remnant ablation. $J$ Korean Acad Nurs. 2013 Dec;43(6):801-11. doi: 10.4040/ jkan.2013.43.6.801

4. Parker WA, Edafe O, Balasubramanian SP. Longterm treatment-related morbidity in differentiated thyroid cancer: a systematic review of the literature. Pragmat Obs Res. 2017 May 16;8:57-67. doi: 10.2147/ POR.S130510. eCollection 2017.

5. Klein Hesselink EN, Klein Hesselink MS, deBock GH, Gansevoort RT, Bakker SJ, Vredeveld EJ, vander Horst-Schrivers AN, vander Horst IC, Kamphuisen PW, Plukker JT, Links TP, Lefrandt JD. Long-term cardiovascula rmortality in patients with differentiated thyroid carcinoma: anobservational study. J ClinOncol. 2013 Nov 10;31(32):4046-53. doi: 10.1200/JCO.2013.49.1043

6. Abdulrahman RM, Delgado V, Hoftijzer $\mathrm{HC}, \mathrm{Ng}$ AC, Ewe SH, Marsan NA, Holman ER, Hovens GC, Corssmit EP, Romijn JA, Bax JJ, Smit JW. Both exogenous subclinical hyperthyroidism and short-term overt hypothyroidism affect myocardial strain in patients with differentiated thyroid carcinoma. Thyroid. 2011 May;21(5):471-76. doi: 10.1089/thy.2010.0319

7. Sawka AM, Lakra DC, Lea J, Alshehri B, Tsang RW, Brierley JD, Straus S, Thabane L, Gafni A, Ezzat S, George SR, Goldstein DP. A systematic review examining the effects of therapeutic radioactive iodine on ovarian function and future pregnancy in female thyroid cancer survivors. Clin Endocrinol (Oxf). 2008 Sep;69(3):479-90. doi: 10.1111/j.13652265.2008.03222.x

8. Metso S, Jaatinen P, Huhtala H, Luukkaala T, Oksala H, Salmi J. Long-term follow-up study of radioiodine treatment of hyperthyroidism. Clin Endocrinol (Oxf). 2004 Nov;61(5):641-48. doi: 10.1111/j.1365-2265.2004.02152.X

9. Zhang P, Xi H, Yan R. Effects of thyrotropin suppression on lumbar bone mineral density in postmenopausal women with differentiated thyroid carcinoma. Onco Targets Ther. 2018 Oct 9;11:6687-92.

\section{Адрес для корреспонденции}

61024, Украина,

г. Харьков, ул. Пушкинская, д. 82,

Институт медицинской радиологии

им. С.П. Григорьева,

группа медицинской информатики, тел. раб.: +380 (67) 799-36-63,

e-mail: radzishevska@ukr.net,

Радзишевская Евгения Борисовна

\section{Сведения об авторах}

Радзишевская Евгения Борисовна, к.ф-м.н., руководитель группы медицинской информатики, Институт медицинской радиологии и онкологии им. С.П. Григорьева Национальной Академии медицинских наук Украины, доцент кафедры медицинской биологической физики и медицинской информатики, Харьковский Национальный медицинский университет, г. Харьков, Украина.

https://orcid.org/0000-0001-9149-7689

Савченко Антонина Степановна, к.м.н., доцент кафедры онкологии, радиологии и радиационой медицины, Харьковский национальный университет им. В.Н. Каразина, г. Харьков, Украина; doi: 10.2147/OTT.S171282. eCollection 2018.

10. Blackburn BE, Ganz PA, Rowe K, Snyder J, Wan Y, Deshmukh V, Newman M, Fraser A, Smith K, Herget K, Kim J, Kirchhoff AC, Porucznik C, Hanson H, Abraham D, Monroe M, Hashibe M. Reproductive and gynecological complication risks among thyroid cancer survivors. J Cancer Surviv. 2018 Oct;12(5):70211. doi: $10.1007 / \mathrm{s} 11764-018-0707-7$

11. Samadi R, Ghanbari M, Shafiei B, Gheibi S, Azizi F, Ghasemi A. High dose of radioactive iodine per se has no effect on glucose metabolism in thyroidectomized rats. Endocrine. 2017 May;56(2):399-407. doi: 10.1007/ s12020-017-1274-9

12. Lin SY, Hsu WH, Lin CL, Lin CC, Lin JM, Chang YL, Hsu CY, Kao CH. Evidence for an Association between Macular Degeneration and Thyroid Cancer in the Aged Population. Int J Environ Res Public Health. 2018 May 3;15(5):902. doi: 10.3390/ijerph15050902

13. Wang S, Liang $\mathrm{C}$, Zhao L, Meng Z, Zhang C, Jia Q, Tan J, Yang H, Liu X, Wang X. Influence of radioactive iodine therapy on liver function in patients with differentiated thyroid cancer. Nucl Med Commun. 2018 Dec;39(12):1113-20. doi: 10.1097/ MNM.0000000000000919

14. Rawson P, Stockum C, Peng L, Manivannan B, Lehnert K, Ward HE, Berry SD, Davis SR, Snell RG, McLauchlan D, Jordan TW. Metabolic proteomics of the liver and mammary gland during lactation. $J$ Proteomics. 2012 Jul 19;75(14):4429-35. doi: 10.1016/j. jprot.2012.04.019

15. Ajmera VH, Terrault NA, VanWagner LB, Sarkar M, Lewis CE, Carr JJ, Gunderson EP. Longer lactation duration is associated with decreased prevalence of nonalcoholic fatty liver disease in women. J Hepatol. 2019 Jan;70(1):126-32. doi: 10.1016/j.jhep.2018.09.013

16. Velle-Forbord V, Skrestad RB, Salvesen $\varnothing$, Kramer MS, Morken NH, Vanky E. Breastfeeding and long-term maternal metabolic health in the HUNT Study: a longitudinal population-based cohort study. BJOG. 2019 Mar;126(4):526-34. doi: 10.1111/14710528.15538

\section{Address for correspondence}

61024, Ukraine,

Kharkiv, Pushkinskaya Str., 82,

S.P. Grigoriev Institute of Medical Radiology and Oncology, Group of Medical Information

Technology,

tel. office.:+380 (67) 799-36-63,

e-mail: radzishevska@ukr.net,

Radzishevska Yevgenia B.

\section{Information about the authors}

Radzishevska Yevgenia B., PhD (Phys., Biol. Science) Head of the Group of Medical Information Technology, S.P. Grigoriev Institute of Medical Radiology and Oncology, National Academy of Medical Sciences of Ukraine, Associate Professor of the Department of Medical Biological Physics and Medical Information Technology, Kharkiv National Medical University, Kharkiv, Ukraine.

https://orcid.org/0000-0001-9149-7689

Savchenko Antonina S., PhD, Associate Professor of the Department of Oncology, Radiology and Radiation Medicine, Kharkiv State University Named after V.N.Karazin, Radiologist of the Nuclear Medicine 
врач-радиолог отделения ядерной медицины, Институт медицинской радиологии и онкологии им. С.П. Григорьева Национальной Академии медицинских наук Украины.

https://orcid.org/0000-0002-7055-117X

Радзишевская Ярослава Константиновна, к.м.н., врач-терапевт, ультразвуковой диагност, Харьковская городская клиническая больница № 27, г. Харьков, Украина.

https://orcid.org/0000-0003-0770-3852

Выговская Людмила Анатольевна, д.мед.н., доцент кафедры акушерства, гинекологии и детской гинекологии, Харьковский национальный медицинский университет, г. Харьков, Украина.

https://orcid.org/0000-0002-9389-4845

Бойко Алексей Николаевич, к.м.н., заведующий терапевтическим отделением, Харьковская городская клиническая больница № 27, г. Харьков, Украина. https://orcid.org/0000-0003-2865-2951

Куксина М. С., магистр по биологии, École Normale Supérieure. Высшая школа, г. Лион, Французская Республика.

https://orcid.org/0000-0001-8244-346X

\section{Информация о статье}

Поступила 12 февраля 2021 г.

Принята в печать 25 октября 2021 года Доступна на сайте 1 января 2022 г.
Department, S.P. Grigoriev Institute of Medical Radiology and Oncology, National Academy of Medical Sciences of Ukraine, Kharkiv, Ukraine. https://orcid.org/0000-0002-7055-117X

Radzishevska Yaroslava K., PhD, Therapist, US Specialist, Kharkiv City Clinical Hospital No27, Kharkiv, Ukraine.

https://orcid.org/0000-0003-0770-3852

Vygivska Ludmila A., MD, Associate Professor of the Department of Obstetrics, Gynecology and Pediatric Gynecology, Kharkiv National Medical University, Kharkiv, Ukraine.

https://orcid.org/0000-0002-9389-4845

Boiko Alexey N., PhD, Head of the Therapeutic Department, Kharkiv City Clinical Hospital No27, Kharkiv, Ukraine.

https://orcid.org/0000-0003-2865-2951

Kuksin M.S., Master of Biology, École Normale Supérieure. Higher School, Lyon, France.

https://orcid.org/0000-0001-8244-346X

\section{Article history}

Arrived: 12 February 2021

Accepted for publication: 25 October 2021

Available online: 1 January 2022 